
Military Technical College Kobry El-Kobbah, Cairo, Egypt

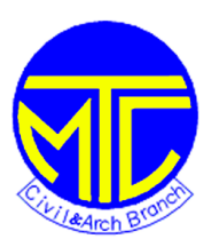

\section{$10^{\text {th }}$ International Conference on Civil and Architecture Engineering}

ICCAE-10-2014

\title{
Environmental Impact Assessment of Shubra Al-Kheima Power Plant
}

\author{
Y. Alamiri ${ }^{*}$, M. Abd El-Razek ${ }^{\ddagger}$, N. Amer ${ }^{\dagger}$, S. Mahfouz ${ }^{\S}$
}

\begin{abstract}
This paper discusses the environmental impact assessment (EIA) for Shubra Al-Kheima power plant in Egypt. The study focuses on the air pollution problem caused by of fuel combustion in the boilers of thermal power plant. Pollutant emissions from the thermal power plants represented in sulphur oxides $\left(\mathrm{SO}_{2}\right)$, nitrogen oxides $\left(\mathrm{NO}_{2}\right)$, and particulate matter $\left(\mathrm{PM}_{10}\right)$. Therefore, severe restrictions and controls are taken into consider to assess the environmental impacts of such projects, before implementation, and during the operation of these projects. In this study, Industrial Source Complex software (ISCST3) is utilized to study the effects of pollution caused by emissions from stacks of the Shubra Al-Kheima station. The study is based on maximum hourly $\left(\mathrm{M}_{\mathrm{H}}\right)$ and maximum daily $\left(\mathrm{M}_{\mathrm{D}}\right)$ prediction of $\mathrm{SO}_{2}, \mathrm{NO}_{2}$ and $\mathrm{PM}_{10}$ concentrations at two different locations.

The results of the concentrations of $\mathrm{PM}_{10}, \mathrm{NO}_{2}$, and $\mathrm{SO}_{2}$ are compared with the limits stated by Egyptian Environmental Affairs Agency (EEAA), World Bank Environmental Law (WE), Environmental Standards in (U.S)-(ESUS) and Air Quality Standards for (U.K)-(AQSUK).
\end{abstract}

\section{Keywords}

Shubra Al-Kheima power plant, Environmental Impact Assessment, Air pollution, ISCST3 model,

\footnotetext{
*_Libyan Army, Libya. Email: murm2007@yahoo.com

$\ddagger \quad$ Arab Academy for Science, Technology and Maritime Transport, Egypt

$\dagger \quad$ Egyptian Armed Forces, Military Technical College, Egypt

$\S \quad$ Egyptian Armed Forces, Military Technical College, Egypt
} 


\section{Nomenclature}

$\begin{array}{cl}\text { EIA } & \text { Environmental Impact Assessment } \\ \text { EEAA } & \text { Egyptian Environmental Affairs Agency } \\ \text { ISCST3 } & \text { Industrial Source Complex Short Term } \\ \text { WBEL } & \text { World Bank Environmental Law } \\ \text { ESUS } & \text { Environmental Standards (U.S) } \\ \text { EU } & \text { European Union } \\ \text { AQSUK } & \text { Air Quality Standards (U.K) } \\ \text { EPA } & \text { Environmental Protection Agency } \\ \text { CDM } & \text { Clean Development Mechanism } \\ \mathrm{PM}_{10} & \text { Particulate Matter } \\ \mathrm{NO}_{2} & \text { Nitrogen oxide } \\ \mathrm{CO}_{\mathrm{CO}} & \text { Carbon monoxide } \\ \mathrm{CO}_{2} & \text { Carbon dioxide } \\ \mathrm{SO}_{2} & \text { Sulphur dioxide } \\ \mathrm{M}_{\mathrm{H}} & \text { Maximum Hourly } \\ \mathrm{M}_{\mathrm{D}} & \text { Maximum Daily } \\ \mathrm{X} & \text { vertical direction of the map } \\ \mathrm{Y} & \text { horizontal direction of the map } \\ \mathrm{USEPA}_{\mathrm{K}} & \text { United States Environment Protection Agency } \\ \mathrm{K} & \text { Kelvin }\end{array}$

\section{Introduction}

Environmental Impact Assessment (EIA) [1] is a process which identifies the environmental effects (both negative and positive) of development proposals. It aims to prevent, reduce and offset any adverse impacts. This involves data collection and environmental studies to identify the effects and propose mitigation measures. The environmental impact assessment must identify the direct and indirect effects of a project on soil, water and air. The (EIA) process emphasizes on the reduce harmful effects on the environment arising from new establishments and extensions of existing establishments, according to Executive Regulations for the environment, Egyptian Low No.4/1994 [2]. Egyptian laws and regulations specify the technical scope and contents of an environmental impact assessment.

The previous studies aimed to reduce the negative impacts affecting the environment resulting from the power plants and other projects, among them: Egyptian Environmental Affairs Agency (EEAA) was commissioned to prepare the technical documents and procedures required concerning the environmental impact assessment of the proposed Tebbin thermal power project [3] at the old Tebbin power plant location. The results of the assessment work have been compared with the environmental standards set by the Government of the Arab Republic of Egypt and the World Bank, whichever is the more stringent. The conclusions of the assessment are that the project is in compliance with the environmental requirements of both the Government of Egypt and the World Bank. According to the (EIA) Regulation enacted in Turkey, Peker et.al [4] primarily aimed to provide educational support for (EIA) practices and decision-makers on energy-generating power stations. 
CEDINFO to be used for EIA for energy-generating stations was designed. CEDINFO primarily aims to provide educational support for EIA practices and decision-makers on energy-generating stations in Turkey.

Another study [5] EIA studies at the project stage prior to the construction and operation of the particular facility under assessment. In this particular study ISCST3 software was applied aiming to simulate the dispersion of $\mathrm{NO}_{2}$. Input data to ISCST3 model includes meteorological parameters measured near the power plant stations located in central Portugal. A large number of simulations-were performed in order to compare the results with EU regulations.

In the current study, ISCST3 model is applied to investigate the effects of pollution caused by emissions from stacks of the Shubra Al-Kheima power plant. The study is based on maximum hourly $\left(\mathrm{M}_{\mathrm{H}}\right)$ and maximum daily $\left(\mathrm{M}_{\mathrm{D}}\right)$ prediction of $\mathrm{SO}_{2}, \mathrm{NO}_{2}$ and $\mathrm{PM}_{10}$ concentrations at two locations. The results found for the concentrations of $\mathrm{PM}_{10}, \mathrm{NO}_{2}$, and $\mathrm{SO}_{2}$ are compared with the limits stated by Egyptian Environmental Affairs Agency (EEAA), World Bank Environmental Law (WBEL), Environmental Standards in (U.S)(ESUS) and Air Quality Standards for (U.K)-(AQSUK).

\section{Emissions from stack of power stations}

One of the definitions the air pollution is the presence in the atmosphere of one or more contaminants tends to be injurious, and can cause health problems and it can also damage the environment and property. The six major types of pollutants are carbon monoxide, hydrocarbons, nitrogen oxides, particulates, sulfur dioxide, and photochemical oxidants. Most of these gases are found naturally in the environment but their levels have been raised artificially by emissions from electricity generation and industry. The main greenhouse gases are: (1) Sulphur dioxide $\left(\mathrm{SO}_{2}\right)$ is a gas produced from burning coal, mainly in thermal power plants. Some industrial processes, such as production of paper and smelting of metals, produce sulphur dioxide. It is a major contributor to smog and acid rain. Sulfur dioxide can lead to lung diseases. (2) Nitrogen oxide $\left(\mathrm{NO}_{2}\right)$ causes smog and acid rain it is produced from burning fuels including petrol, diesel, and coal. Nitrogen oxides can make children susceptible to respiratory diseases in winters. (3) Particulate matter $\left(\mathrm{PM}_{10}\right)$ is the fraction of suspended particles (10) micrometers in diameter and smaller that will enter the nasal cavity. Pollutant emissions from the industrial sector and electric utilities contribute greatly to environmental problems [6].

\section{International environmental laws}

The Egyptian laws No. 4/1994 [2] states that the environmental impact of certain establishments or projects must be evaluated before any construction works are initiated or a license is issued by the competent administrative authority or licensing authority. The executive regulations relating to Law No. (4) identifies the types of establishments or projects which must be subjected to an EIA based upon the following main principles: type of activity performed by the establishment, extent of natural resources exploitation, location of the establishment and type of energy used to operate the establishment. Egypt has developed strategy emission reductions through the Clean Development Mechanism (CDM) of the Kyoto Protocol [7]. The Kyoto Protocol in Japan is an international 
agreement setting targets for industrialized countries to cut their greenhouse gas emissions. These gases are considered at least partly responsible for global warming (the rise in global temperature) which may have catastrophic consequences for life on Earth. Industrialized countries have committed to cut their combined emissions to 5\% below 1990 levels by 2008 - 2012. The Egyptian Emission Standards are shown in the table (1).

Table (1) The Egyptian Law 4 / 1994 ceilings for air pollutants

\begin{tabular}{|c||c||c|}
\hline Pollutant & Standard $\left(\mu \mathrm{g} / \mathrm{m}^{3}\right)$ & Averaging time \\
\hline \hline $\mathrm{PM}_{10}$ & 150 & 24-hour \\
\hline \hline \multirow{3}{*}{$\mathrm{SO}_{2}$} & 350 & 1-hour \\
\cline { 2 - 3 } & 150 & 24-hour \\
\cline { 2 - 3 } & 60 & Annual \\
\hline \multirow{3}{*}{$\mathrm{NO}_{2}$} & 400 & 1-hour \\
\cline { 2 - 3 } & 150 & 24-hour \\
\cline { 2 - 3 } & 70 & Annual \\
\hline
\end{tabular}

The World Bank guidelines for power plant [8] include environmental impact assessment as an integral part of the evaluations that the World Bank performs before financing a proposed project, thermal power plants projects require a full environmental assessment. World Bank air emission guidelines for thermal power plants are shown in the table (2).

Table (2) World Bank air emission guidelines for thermal power plants

\begin{tabular}{|c||c||c|}
\hline Pollutant & Standard $\left(\mu \mathrm{g} / \mathrm{m}^{3}\right)$ & Average time \\
\hline \hline \multirow{2}{*}{$\mathrm{PM}_{10}$} & 50 & Annual \\
\cline { 2 - 3 } & 150 & 24 hour \\
\hline \hline \multirow{2}{*}{$\mathrm{SO}_{2}$} & 80 & Annual \\
\cline { 2 - 3 } & 150 & 24 hour \\
\hline \hline \multirow{2}{*}{$\mathrm{NO}_{2}$} & 100 & Annual \\
\cline { 2 - 3 } & 150 & 24 hour \\
\hline
\end{tabular}

For a clean air the Environmental Protection Agency (EPA) has set the United States National Ambient Air Quality Standards [9] for principal pollutants (i.e criteria) which considered harmful to public health and the environment. Table (3) shows the Environmental Standards in the US.

Table (3) Environmental Standards in the United States

\begin{tabular}{|c||c||c|}
\hline Pollutant & Standard $\left(\mu \mathrm{g} / \mathrm{m}^{3}\right)$ & Average time \\
\hline \hline $\mathrm{PM}_{10}$ & 150 & 24-hour \\
\hline \hline \multirow{3}{*}{$\mathrm{SO}_{2}$} & 365 & 24-hour \\
\cline { 2 - 3 } & 80 & annual \\
\cline { 2 - 3 } & 1,300 & 3-hour \\
\hline \hline $\mathrm{NO}_{2}$ & 100 & annual \\
\hline
\end{tabular}


The objectives adopted in the UK are defined in the latest Air Quality Strategy for England; those which are limiting values required by EU Daughter Directives on Air Quality that have been transposed into UK law through the Air Quality Standards Regulations [10]. Table (4) shows the Air Quality Standards for UK.

Table (4) Air Quality Standards for UK

\begin{tabular}{|c||c||c|}
\hline Pollutant & Standard $\left(\mu \mathrm{g} / \mathrm{m}^{3}\right)$ & Average time \\
\hline \hline \multirow{2}{*}{ NO } & 200 & 1-hour \\
\cline { 2 - 3 } & 40 & Annual \\
\hline \multirow{2}{*}{$\mathrm{PM}_{10}$} & 50 & 24 hour \\
\cline { 2 - 3 } & 40 & Annual \\
\hline \hline \multirow{3}{*}{$\mathrm{SO}_{2}$} & 350 & 1-hour \\
\cline { 2 - 3 } & 125 & 24-hour \\
\hline
\end{tabular}

\section{Air pollution dispersion models}

The objective of a model is to relate mathematically the effects of source emissions on ground level concentrations, and to establish that permissible levels are, or are not, being exceeded. Models have been developed to meet these objectives for a variety of pollutants and time circumstances. The most widely used models for predicting the impact of relative uncreative gases, released from smokestacks are based on Gaussian diffusion [11]. Such models are important to governmental agencies tasked with protecting and managing the ambient air quality. The models are typically employed to determine whether existing or proposed new power plants are in compliance with the Air Quality Standards or not.

\section{ISCST3 model}

In this study, the Industrial Source Complex Short-Term (ISC3ST) model has been used. The model is an advanced Gaussian dispersion model approved by the United States Environment Protection Agency (USEPA) for use in regulatory assessments undertaken within the United States. The model characteristics are:

a) Horizontal and vertical dispersion can be represented by plume spread that is a function of horizontal and vertical turbulence scales.

b) Gaussian models use a statistical parameterization of stability in terms of boundary layer turbulence profiles. See the ISCST3 model in the figure (1).

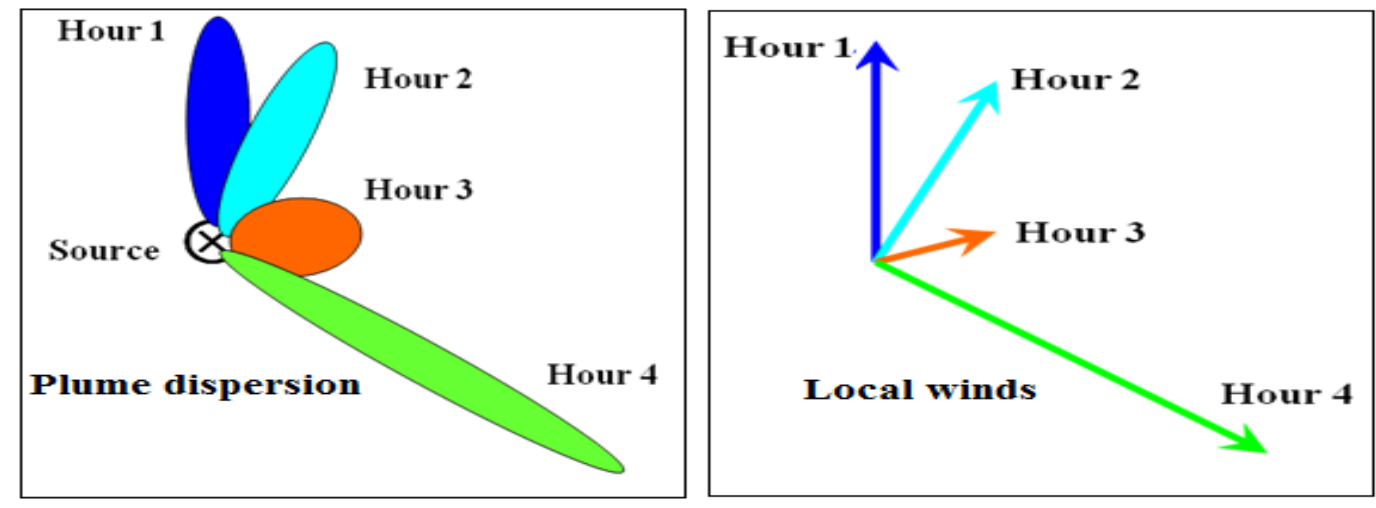

Fig.(1) ISCST3 model 
c) Despite reasonable model validation results, this formulation does not:

i- Allow the plume to evolve over time

ii- Allow the plume to respond to terrain effects

iii- Allow for recirculation of the plume in areas of stagnation or complex Winds.

iv- Allow for the plume to be mixed or partially mixed above the mixed layer.

d) Use of a single meteorological observation limits spatial resolution of plume growth and advection.

The input data required for the ISCST3 model are:

(1) The coordinates of the station from the map of air. This is considered as the main axes of the station.

(2) The coordinates of the stack from the main axes of station on the map.

(3) Stack height $\left(\mathrm{S}_{\mathrm{H}}\right)(\mathrm{m})$

(4) Emission temperature $\left(E_{T}\right)$ for each stack

(5) Stack diameter $\left(\mathrm{S}_{\mathrm{D}}\right)(\mathrm{m})$

(6) Emission velocity $\left(E_{V}\right)$ in the $(\mathrm{m} / \mathrm{s})$

(7) Gases emitted from the stacks (tons/year).

\section{Application to Shubra Al-Kheima Station}

The station consists of a four steam turbines, the general specifications for the station are:

1) Type of fuel natural gas

2) Area of the station $=136,194 \mathrm{~m}^{2}$

3) The coordinates of the station are: $30.22 \mathrm{~N}$ and $31.26 \mathrm{E}$

4) Load factor $=76 \%$

5) Capacity factor $=78 \%$

6) Efficiency $=38.6 \%$

7) Availability $=95.88 \%$

The common characteristics of the four stacks are:

1) Stack height $=123 \mathrm{~m}$

2) Stack diameter $=4.6 \mathrm{~m}$

3) Unit capacity $=315 \mathrm{MW}$

4) The number of operating days per year $=350$ days

5) Temperature of stack gases $=121^{\circ} \mathrm{C}$

6) Total unit capacity $=1260 \mathrm{MW}$

Other characteristics as given in table (5).

Table (5) other characteristics for Shubra al-Kheima station

\begin{tabular}{|c||c||c|c|}
\hline Stacks no. & $\begin{array}{c}\text { Fuel consumption } \\
\left(\mathrm{m}^{3} / \mathrm{s}\right)\end{array}$ & $\begin{array}{c}\text { Rate of fuel consumption } \\
(\mathrm{kg} / \mathrm{hr})\end{array}$ & $\begin{array}{c}\text { Rate of gas flow } \\
(\mathrm{kg} / \mathrm{hr})\end{array}$ \\
\hline \hline 1 & 18.82 & 48093 & 961860 \\
\hline \hline 2 & 18.77 & 47990 & 863820 \\
\hline \hline 3 & 23.98 & 61288 & 1072542 \\
\hline \hline 4 & 18.80 & 48178 & 847933 \\
\hline
\end{tabular}


The ISCST3 model is applied to study the effects of pollution caused by emissions from Shubra Al-Kheima station stacks. All the data required (i.e rates concentration of gases in the air) to operate ISCST3 model considered are give in table (6). The proportions of each gas concentration in the air for the first three months. The applications of the program to extract the desired results are performed.

Table (6) Input data introduced in ISCST3 model for station

\begin{tabular}{|c||c||c||c||c||c|c|c||c||c||c|}
\hline Stack no. & $\begin{array}{c}\mathrm{X} \\
(\mathrm{m})\end{array}$ & $\begin{array}{c}\mathrm{Y} \\
(\mathrm{m})\end{array}$ & $\begin{array}{c}\mathrm{S}_{\mathrm{H}} \\
(\mathrm{m})\end{array}$ & $\begin{array}{c}\mathrm{S}_{\mathrm{T}} \\
(\mathrm{K})\end{array}$ & $\begin{array}{c}\mathrm{S}_{\mathrm{D}} \\
(\mathrm{m})\end{array}$ & $\begin{array}{c}\mathrm{E}_{\mathrm{V}} \\
\mathrm{m} / \mathrm{s}\end{array}$ & $\begin{array}{c}\mathrm{SO}_{2} \\
\mathrm{t} / \mathrm{y}\end{array}$ & $\begin{array}{c}\mathrm{NO}_{2} \\
\mathrm{t} / \mathrm{y}\end{array}$ & $\begin{array}{c}\mathrm{PM}_{10} \\
\mathrm{t} / \mathrm{y}\end{array}$ & Type fuel \\
\hline \hline 1 & 48 & 323 & 123 & 394 & 4.60 & 19.8 & 0.0 & 1925.3 & 52.0 & NG \\
\hline \hline 2 & 29 & 345 & 123 & 394 & 4.60 & 25.2 & 0.0 & 2459.7 & 66.4 & NG \\
\hline \hline 3 & 0 & 356 & 123 & 394 & 4.60 & 19.8 & 0.0 & 1925.3 & 53.4 & NG \\
\hline
\end{tabular}

Fuel used in the station is natural gas only and therefore the results of $\mathrm{SO}_{2}$ emission is zero and the results of the emissions concentrations of $\mathrm{PM}_{10}, \mathrm{NO}_{2}$, in the air from stacks of station will be investigated.

\section{Analysis of results}

Figure (2) and (3) shows concentrations $\left(\mathrm{PM}_{10}\right)$ in the air for the emissions from stacks of Shubra al-Kheima power station. Figure (2) shows that the concentrations $\left(\mathrm{PM}_{10}\right)$ considering the maximum hourly $\left(\mathrm{M}_{\mathrm{H}}\right)$ are found to range between (5.0-1.5) $\mu \mathrm{g} / \mathrm{m}^{3}$. Figure (3) shows that the concentrations $\left(\mathrm{PM}_{10}\right)$ considering the maximum daily $\left(\mathrm{M}_{\mathrm{D}}\right)$ are found to range between concentrations (1.5-0.2) $\mu \mathrm{g} / \mathrm{m}^{3}$.

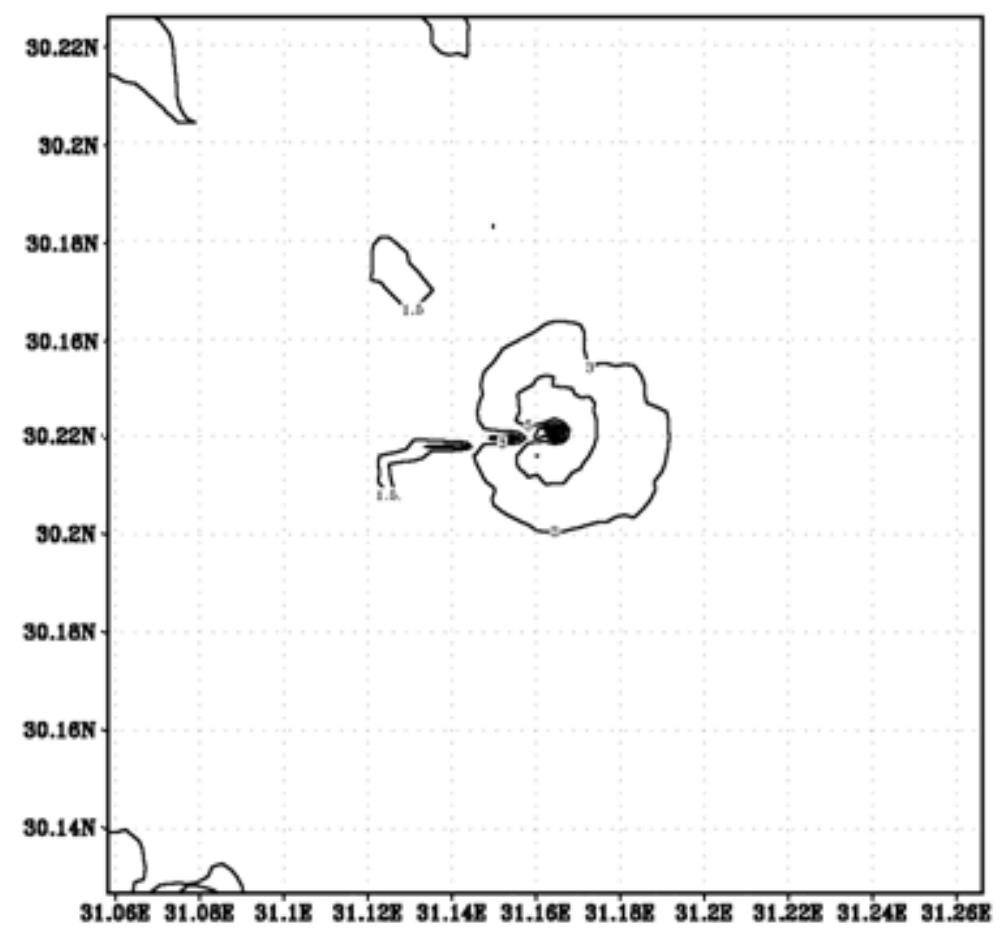

Fig. (2) $\mathrm{PM}_{10}$ concentrations in the air- $\mathrm{M}_{\mathrm{H}}$ 


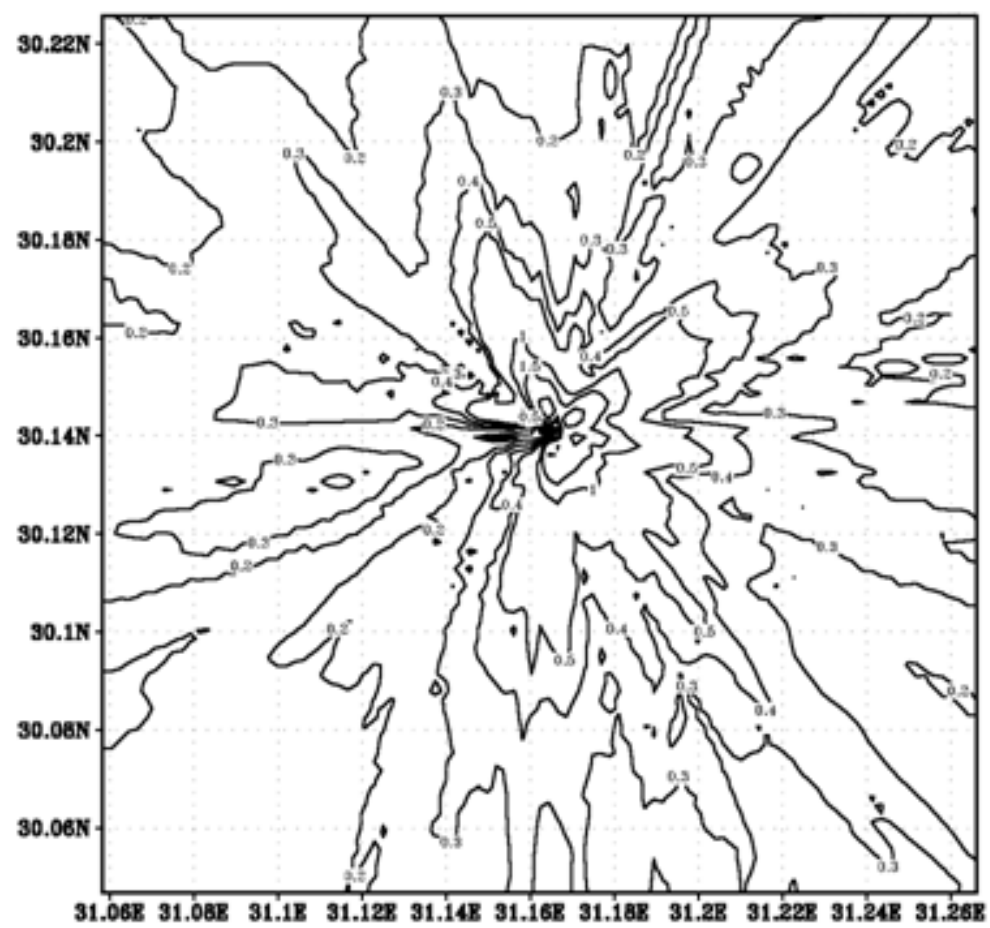

Fig. (3) $\mathbf{P M}_{10}$ concentrations in the air- $\mathbf{M}_{D}$

Figure (4) and (5) shows concentrations $\left(\mathrm{NO}_{2}\right)$ in the air for the emissions from stacks of the station. Figure (4) shows that the Concentrations $\left(\mathrm{NO}_{2}\right)$ considering the maximum hourly $\left(\mathrm{M}_{\mathrm{H}}\right)$ are found to range between (70-30) $\mu \mathrm{g} / \mathrm{m}^{3}$. Figure (5) shows that the concentrations $\left(\mathrm{NO}_{2}\right)$ considering the Maximum daily $\left(\mathrm{M}_{\mathrm{D}}\right)$ are found to range between $(250-50) \mu \mathrm{g} / \mathrm{m}^{3}$.

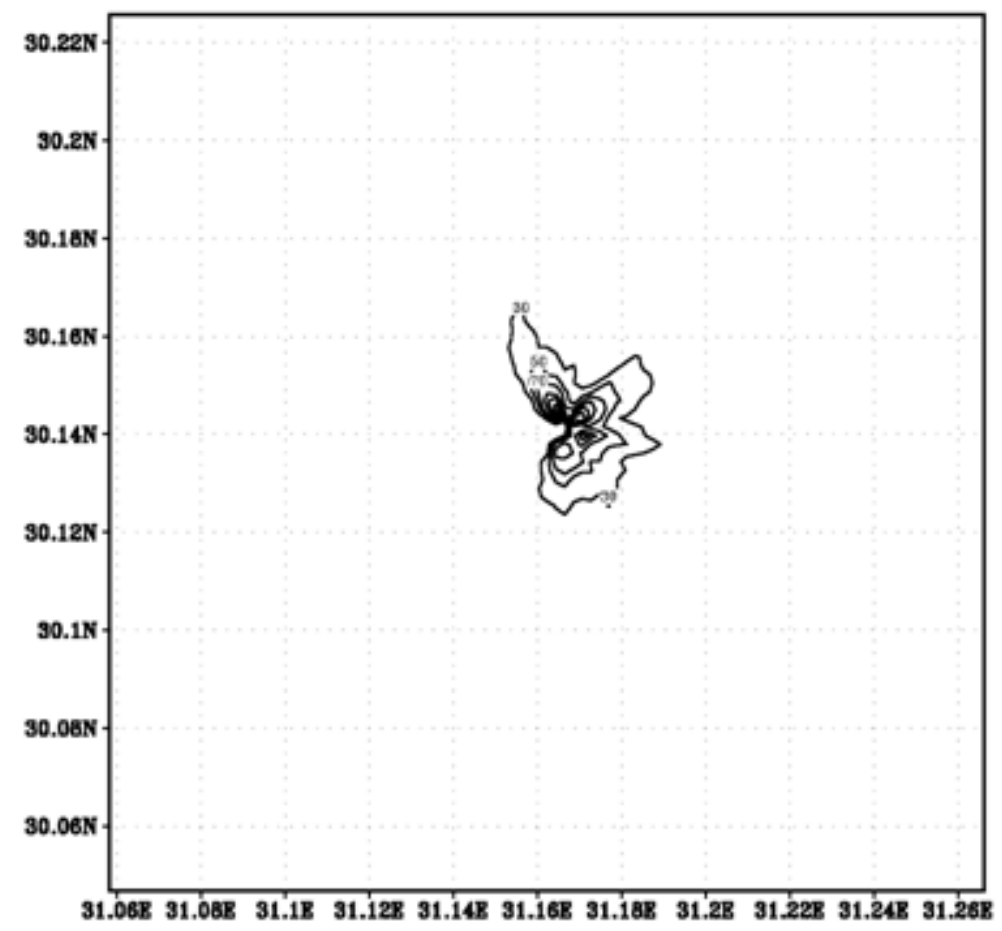

Fig. (4) $\mathrm{NO}_{2}$ concentrations in the air- $\mathrm{MH}_{\mathrm{H}}$ 


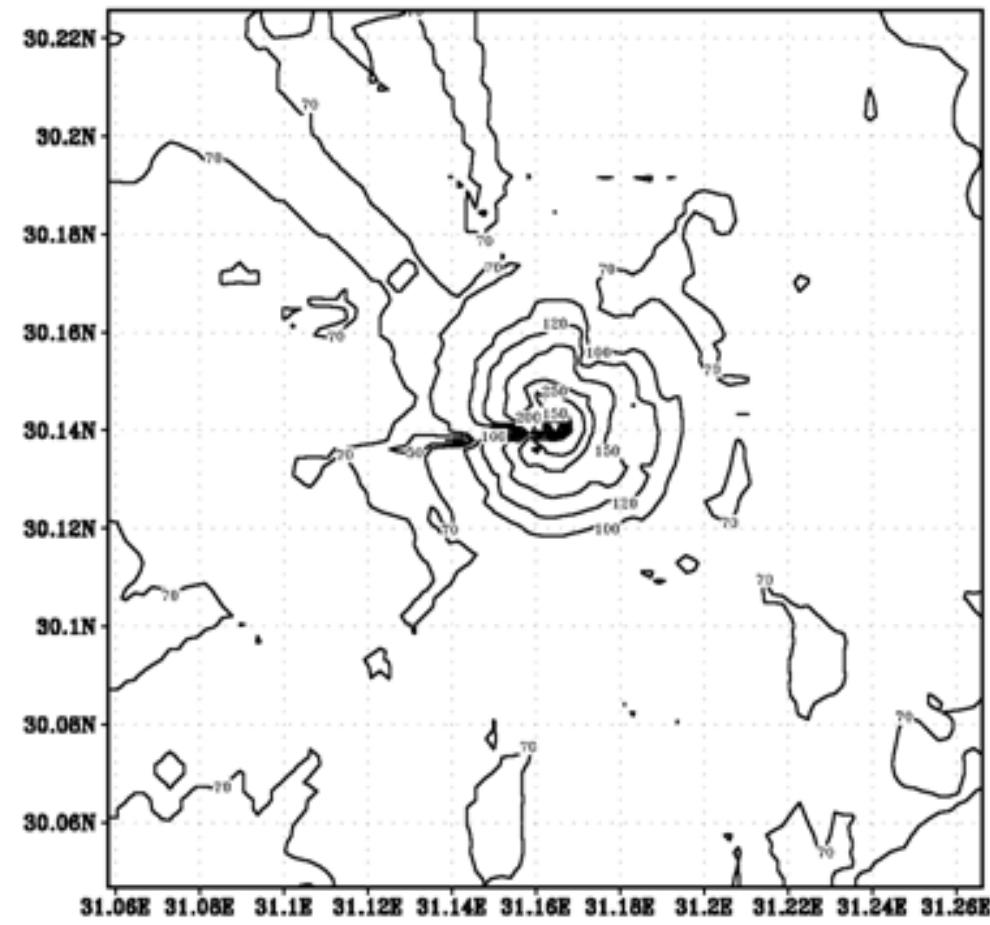

Fig. (5) $\mathrm{NO}_{2}$ concentrations in the air-M

Two locations have been selected to measure the emissions. The first location is within the station site and the coordinates of first location (30.1334 N, 31.1686 E), the second location is the residential area the station beside, and the coordinates of second location (30.0898 N, 31.2251 E), shown of the results in table (7).

Table (7) Emissions analysis results at the two locations during three months

\begin{tabular}{|c||c|c||c|c|}
\hline \multirow{2}{*}{ Emissions } & \multicolumn{2}{c||}{ First location } & \multicolumn{2}{c|}{ Second location } \\
\cline { 2 - 5 } & $\begin{array}{c}\text { Maximum hourly } \\
\left(\mu \mathrm{g} / \mathrm{m}^{3}\right)\end{array}$ & $\begin{array}{c}\text { Maximum daily } \\
\left(\mu \mathrm{g} / \mathrm{m}^{3}\right)\end{array}$ & $\begin{array}{c}\text { Maximum hourly } \\
\left(\mu \mathrm{g} / \mathrm{m}^{3}\right)\end{array}$ & $\begin{array}{c}\text { Maximum daily } \\
\left(\mu \mathrm{g} / \mathrm{m}^{3}\right)\end{array}$ \\
\hline \hline $\mathrm{PM}_{10}$ & 5.0 & 1.80 & 1.81 & 0.31 \\
\hline $\mathrm{NO}_{2}$ & 185 & 65 & 67 & 11.5 \\
\hline
\end{tabular}

\section{Comparison between results obtain and international environmental law}

The results found for the concentrations of $\mathrm{PM}_{10}, \mathrm{NO}_{2}$, are compared with the limits stated by Egyptian Environmental Affairs Agency (EEAA), World Bank Environmental Law (WBEL), Environmental Standards in (ES-US) and Air Quality Standards for (AQS-UK). These comparisons are given in tables (8), (9). From these tables it can be noticed that:

\section{Table (8) comparisons at first location}

\begin{tabular}{|c|c|c|c|c|c|c|c|c|c|c|}
\hline \multirow[t]{3}{*}{ Emissions } & \multirow{2}{*}{\multicolumn{2}{|c|}{$\begin{array}{c}\text { Value of } \\
\text { emissions } \\
\left(\mu \mathrm{g} / \mathrm{m}^{3}\right)\end{array}$}} & \multicolumn{2}{|c|}{$\begin{array}{c}\text { Egyptian } \\
\text { Environmental } \\
\text { Law (EE) } \\
\end{array}$} & \multicolumn{2}{|c|}{$\begin{array}{c}\text { World Bank } \\
\text { Environmental } \\
\text { Law (WB) } \\
\end{array}$} & \multicolumn{2}{|c|}{$\begin{array}{c}\text { Environmental } \\
\text { Standards in } \\
\text { (U.S) }\end{array}$} & \multicolumn{2}{|c|}{$\begin{array}{l}\text { Air Quality } \\
\text { Standards } \\
\text { for (U.K) } \\
\end{array}$} \\
\hline & & & Sta & & & ard & & & $\overline{\text { Sta }}$ & lard \\
\hline & $\mathrm{M}_{\mathrm{H}}$ & $\mathrm{M}_{\mathrm{D}}$ & $\overline{\mathrm{M}_{\mathrm{H}}}$ & $\overline{M_{D}}$ & $\overline{\overline{M_{H}}}$ & $\mathrm{M}_{\mathrm{D}}$ & $\overline{\mathrm{M}_{\mathrm{H}}}$ & $\overline{\mathrm{M}_{\mathrm{D}}}$ & $\overline{\overline{M_{H}}}$ & $\mathrm{M}_{\mathrm{D}}$ \\
\hline $\mathrm{PM}_{10}$ & 5.0 & 1.8 & - & 150 & - & 150 & - & $\overline{150}$ & - & 50 \\
\hline $\mathrm{NO}_{2}$ & 185 & 65 & 400 & 150 & - & 150 & 200 & - & 200 & - \\
\hline $\mathrm{SO}_{2}$ & - & $\overline{-}$ & 350 & 150 & - & 150 & 435 & 365 & 350 & 125 \\
\hline
\end{tabular}


Table (9) comparisons at second location

\begin{tabular}{|c|c|c|c|c|c|c|c|c|c|c|}
\hline \multirow[t]{3}{*}{ Emissions } & \multirow{2}{*}{\multicolumn{2}{|c|}{$\begin{array}{l}\text { Value of } \\
\text { emissions } \\
\left(\mu \mathrm{g} / \mathrm{m}^{3}\right)\end{array}$}} & \multirow{2}{*}{\multicolumn{2}{|c|}{$\begin{array}{c}\text { Egyptian } \\
\text { Environmental } \\
\text { Law (EE) } \\
\text { Standard }\end{array}$}} & \multirow{2}{*}{\multicolumn{2}{|c|}{$\begin{array}{c}\text { World Bank } \\
\text { Environmental } \\
\text { Law (WB) } \\
\text { Standard }\end{array}$}} & \multirow{2}{*}{\multicolumn{2}{|c|}{$\begin{array}{c}\text { Environmental } \\
\text { Standards in } \\
\text { U.S. } \\
\text { Standard }\end{array}$}} & \multirow{2}{*}{\multicolumn{2}{|c|}{$\begin{array}{c}\begin{array}{c}\text { Air Quality } \\
\text { Standards for } \\
\text { (U.K) }\end{array} \\
\text { Standard }\end{array}$}} \\
\hline & & & & & & & & & & \\
\hline & $\overline{M_{H}}$ & $\mathrm{M}_{\mathrm{D}}$ & $\mathrm{M}_{\mathrm{H}}$ & $\mathrm{M}_{\mathrm{D}}$ & $\mathrm{M}_{\mathrm{H}}$ & $\mathrm{M}_{\mathrm{D}}$ & $\mathrm{M}_{\mathrm{H}}$ & $\mathrm{M}_{\mathrm{D}}$ & $\overline{M_{H}}$ & $\overline{M_{D}}$ \\
\hline $\mathrm{PM}_{10}$ & 1.81 & & - & 150 & 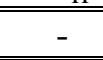 & 150 & - & 150 & - & 50 \\
\hline $\mathrm{NO}_{2}$ & 67 & 11.5 & 400 & 150 & 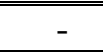 & 150 & 200 & - & 200 & - \\
\hline $\mathrm{SO}_{2}$ & ב--- & --- & 350 & 150 & - & 150 & 435 & 365 & 350 & 125 \\
\hline
\end{tabular}

(1) The fuel used in the station is natural gas only and therefore the results of emissions $\mathrm{SO}_{2}$ are zero.

(2) The emission concentration of particulate matter $\left(\mathrm{PM}_{10}\right)$ in the $\left(\mathrm{M}_{\mathrm{D}}\right),\left(1.8 \mu \mathrm{g} / \mathrm{m}^{3}\right)$ at first location and $\left(\mathrm{M}_{\mathrm{D}}\right)$ is $\left(0.31 \mu \mathrm{g} / \mathrm{m}^{3}\right)$ at second location are found to be less than the limits $\left(150 \mu \mathrm{g} / \mathrm{m}^{3}\right)$ recommended by international environmental laws (EE), (WB), (ESUS).

(3) The emission concentration of nitrogen dioxide $\left(\mathrm{NO}_{2}\right)$ in the $\left(\mathrm{M}_{\mathrm{H}}\right)$ is $\left(185 \mu \mathrm{g} / \mathrm{m}^{3}\right)$ from stacks in the air during the same period was less than the limits $\left(400 \mu \mathrm{g} / \mathrm{m}^{3}\right)$ in the (EE) and the $\left(M_{D}\right)$ is $\left(65 \mu \mathrm{g} / \mathrm{m}^{3}\right)$ was found to be less than the limits $\left(150 \mu \mathrm{g} / \mathrm{m}^{3}\right)$ recommended by (EE), (WB) at first location.

(4) The emission concentration of nitrogen dioxide $\left(\mathrm{NO}_{2}\right)$ in the $\left(\mathrm{M}_{\mathrm{H}}\right)$ is $\left(67 \mu \mathrm{g} / \mathrm{m}^{3}\right)$ from stacks in the air during the same period was less than the limits $\left(400 \mu \mathrm{g} / \mathrm{m}^{3}\right)$ in the (EE) and the $\left(M_{D}\right)$ is $\left(11.5 \mu \mathrm{g} / \mathrm{m}^{3}\right)$ was found to be less than the limits $\left(150 \mu \mathrm{g} / \mathrm{m}^{3}\right)$ recommended by (EE), (WB) at second location.

The comparison between the results of $\mathrm{PM}_{10}$ concentrations emissions in the maximum daily at two locations and all environmental laws, see the figure (6).

Where:

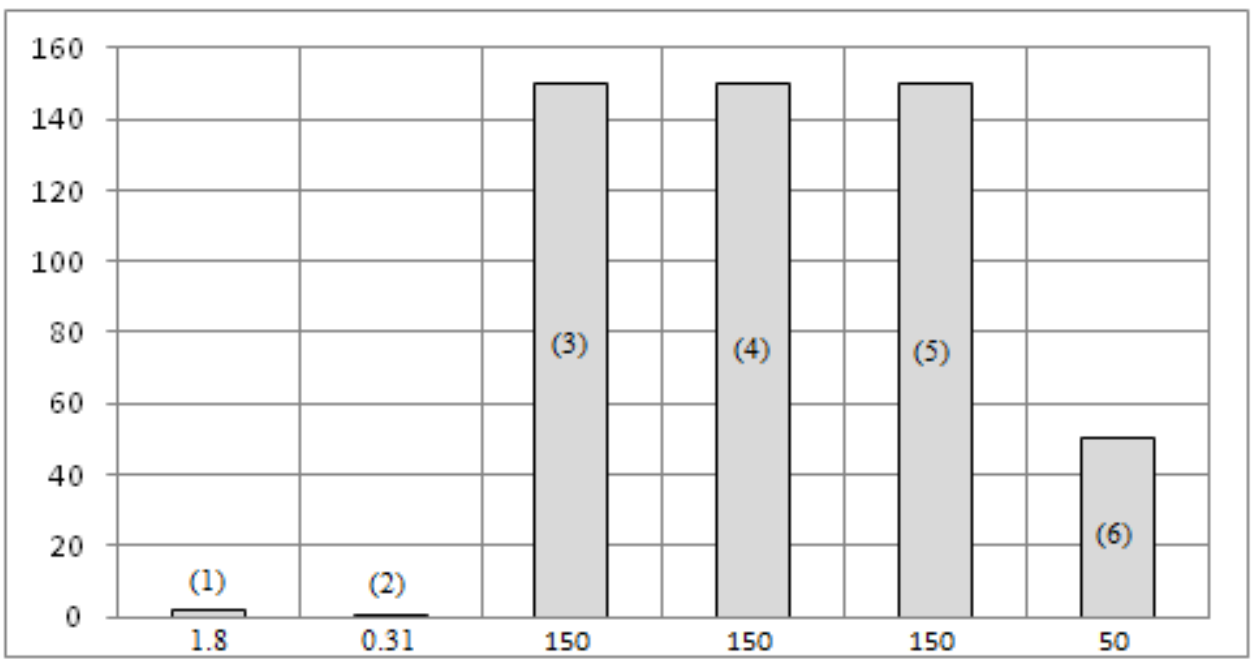
(1) Results of emissions at first location,
(4) World Bank Environmental Law (WB)
(2) Results of emissions at second location,
(5) Environmental Standard in (U.S)
(3) Egyptian Environmental Law (EE),
(6) Air Quality Standard for (U.K) 
Fig.(6) Concentrations $\mathbf{P M}_{10}$ comparison between and environmental laws- $\mathrm{M}_{\mathrm{D}}$ at two location

The comparison between the results of $\mathrm{NO}_{2}$ concentrations emissions in the maximum daily and maximum hourly at two location and all environmental laws, see the figures (7),(8).

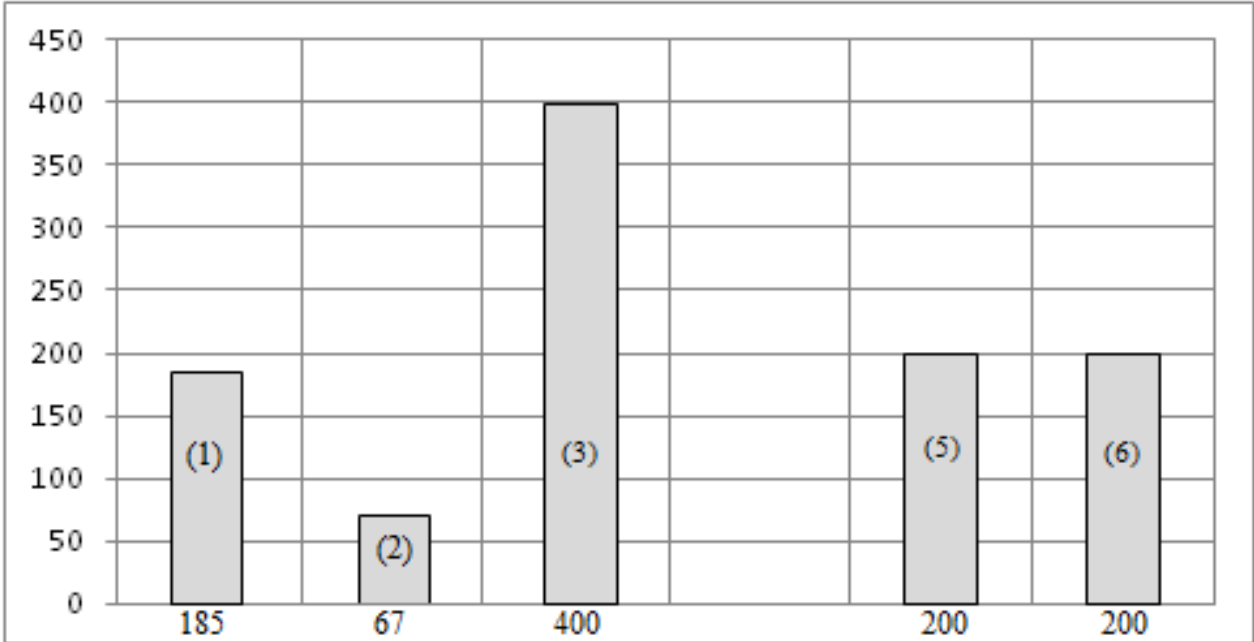

Fig.(7) Concentrations $\mathrm{NO}_{2}$ comparison between and environmental laws $\left(\mathrm{M}_{\mathrm{H}}\right)$ at two location

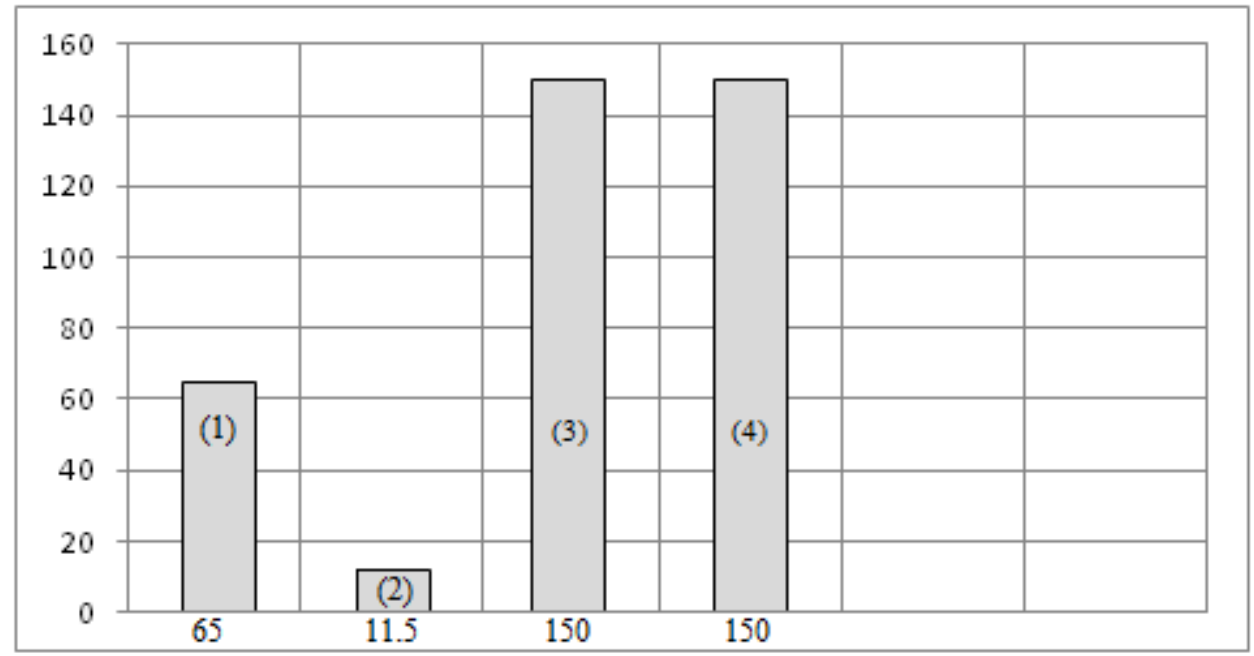

Fig.(7) Concentrations $\mathrm{NO}_{2}$ comparison between and environmental laws $\left(\mathrm{M}_{\mathrm{H}}\right)$ at two location

\section{Conclusion}

The environmental impact assessment (EIA) for Shubra al-Kheima power plant is invesitaged and the results show that:

(1) The emissions from Shubra Al-Kheima station are found to be less than the limits of the Egyptian code and don't violate the environment. 
(2) $\mathrm{PM}_{10}$ and $\mathrm{NO}_{2}$ concentrations in the maximum hourly and daily are within the limits permitted by all environmental laws at two locations.

(3) When using natural gas as fuel (Shubra al-Kheima station) the absence of emissions of sulfur dioxide $\left(\mathrm{SO}_{2}\right)$ is noticed. Concentration of this gas in the air is almost zero.

\section{References}

[1] Larry W., Environmental Impact Assessment, 1999.

[2] Egyptian Environmental Affairs Agency, Guidelines on Egyptian Environmental Impact Assessment. 2000-2001

[3] Egyptian Electricity Holding Company, ESIA for Tebbin thermal power project, 2005.

[4] Nuriye Peker Say, M. Yücel , M. Y1lmazer, A computer-based system for environmental impact assessment (EIA) applications to energy power stations in Turkey, Çukurova University, Balcal1, Adana, Turkey, 2007.

[5] U. S. EPA, User's guide for the industrial source complex (ISC3) dispersion models, Office of Air Quality Planning and Standards; 1995

[6] Richard J Hunwick, A review of control techniques: current and projected Presentation to the Sydney Branch of the Australian Institute of Energy, 2006.

[7] Kyoto Protocol: Status of Ratification, UNFCC Retrieved, 2006.

[8] World Bank Group, Thermal Power - Guidelines for New plants in pollution Prevention and Abatement Handbook - Part III, 1998

[9] EPA working group report on the NAAQS reviews process, 2006.

[10] The Air Quality Strategy for England, Scotland, Wales and Northern Ireland, 2007

[11] Beychok, Milton R. (Fundamentals of Stack Gas Dispersion), 4th Edition, 2005 